This is an author produced version of a paper published in Thrombosis and Haemostasis. This paper has been peer-reviewed and is proofcorrected, but does not include the journal pagination.

Citation for the published paper:

Zhu T, Ubhayasekera W, Nickolaus N, Sun W, Tingsborg S, Mowbray SL, Schedin-Weiss S. (2010) Zinc ions bind to and inhibit activated protein $\mathrm{C}$. Thrombosis and Haemostasis.

Volume: 104 Number: 3, pp 544-53.

http://dx.doi.org/10.1160/TH09-12-0862

Access to the published version may require journal subscription. Published with permission from: Schattauer

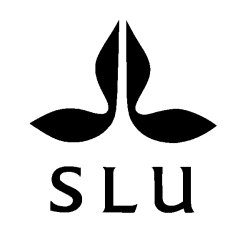

Epsilon Open Archive http://epsilon.slu.se 


\section{Thrombosis and Haemostasis}

\section{Zinc ions bind to and inhibit activated protein $\mathrm{C}$}

\begin{tabular}{|r|l|}
\hline Journal: & Thrombosis and Haemostasis \\
\hline Manuscript ID: & TH-09-12-0862.R3 \\
\hline Manuscript Type: & $\begin{array}{l}\text { Basic/Clinical Studies: blood coagulation, fibrinolysis and cellular } \\
\text { haemostasis }\end{array}$ \\
\hline Category: & Basic Science \\
\hline Date Submitted by the & n/a \\
\hline Author: & $\begin{array}{r}\text { Zhu, Tianqing; Uppsala University } \\
\text { Ubhayasekera, Wimal; Lund University } \\
\text { Nickolaus, Noelle; Europe University of Applied Sciences } \\
\text { Sun, Wei; Uppsala University } \\
\text { Tingsborg, Susanne; Uppsala University } \\
\text { Mowbray, Sherry; Swedish University of Agricultural Scinces } \\
\text { Schedin-Weiss, Sophia; Uppsala University }\end{array}$ \\
\hline Keywords: & $\begin{array}{l}\text { Protein function / activity, Coagulation inhibitors, Protease } \\
\text { inhibitors, Proteases, Protein C/S pathway }\end{array}$ \\
\hline
\end{tabular}

\section{s) ScholarONE \\ Manuscript Central}




\section{ZINC IONS BIND TO AND INHIBIT ACTIVATED PROTEIN C}

\section{Tianqing Zhu' ${ }^{1}$, Wimal Ubhayasekera ${ }^{2 \S}$, Noëlle Nickolaus ${ }^{1}$, Wei Sun ${ }^{1}$, Susanne}

Tingsborg $^{1}$, Sherry L. Mowbray ${ }^{2,3}$ and Sophia Schedin-Weiss ${ }^{1}$

${ }^{1}$ Department of Medical Biochemistry and Microbiology, Uppsala University; ${ }^{2}$ Department of Molecular Biology, Swedish University of Agricultural Sciences and ${ }^{3}$ Department of Cell and Molecular Biology, Uppsala University, Uppsala, Sweden.

${ }^{\S}$ Present address: MAX-lab, Lund University, Lund, Sweden and Institute of Medicinal Chemistry, University of Copenhagen, Copenhagen $\varnothing$, Denmark.

Running title: $\mathrm{Zn}^{2+}$ inhibits activated protein $\mathrm{C}$

\section{Correspondence to:}

Sophia Schedin Weiss, $\mathrm{PhD}$

Department of Medical Biochemistry and Microbiology

Uppsala University, Box 582

SE-751 23 Uppsala, Sweden.

Tel.: +4618 4716655, Fax: +46184714673

E-mail: Sophia.Schedin_Weiss@imbim.uu.se

Financial support: This work was supported by Swedish Research Council grants 2003-6107, 2005-6412 and 2007-4444 and by the Magnus Bergvall foundation (to S.S.W.). 


\section{Summary}

$\mathrm{Zn}^{2+}$ ions were found to efficiently inhibit activated protein $\mathrm{C}$ (APC), suggesting a potential regulatory function for such inhibition. APC activity assays employing a chromogenic peptide substrate demonstrated that the inhibition was reversible and the apparent $K_{\mathrm{I}}$ was $13 \pm 2 \mu \mathrm{M} . k_{\mathrm{cat}}$ was 7 -fold decreased whereas $K_{\mathrm{M}}$ was unaffected in the presence of $10 \mu \mathrm{M}$ $\mathrm{Zn}^{2+}$. The inhibitory effect of $\mathrm{Zn}^{2+}$ on APC activity was also observed when factor Va was used as a substrate in an assay coupled to a prothrombinase assay. The interaction of $\mathrm{Zn}^{2+}$ with APC was accompanied by a reversible $\sim 40 \%$ decrease in tryptophan fluorescence, consistent with the ion inducing a conformational change in the protein. The apparent $K_{\mathrm{D}}$ was $7.4 \pm 1.5 \mu \mathrm{M}$ and thus correlated well with the apparent $K_{\mathrm{I}}$. In the presence of physiological $\mathrm{Ca}^{2+}$ concentration the $K_{\mathrm{I}}$ and $K_{\mathrm{D}}$ values were 3-4-fold enhanced, presumably due to the $\mathrm{Ca}^{2+}$-induced conformational change affecting the conformation of the $\mathrm{Zn}^{2+}$-binding site. The inhibition mechanism was non-competitive both in the absence and presence of $\mathrm{Ca}^{2+}$. Comparisons of sequences and structures suggested several possible sites for zinc binding. The magnitude of the apparent $K_{\mathrm{I}}$ in relation to the blood and platelet concentrations of $\mathrm{Zn}^{2+}$ supports a physiological role for this ion in the regulation of anticoagulant activity of APC. These findings broaden the understanding of this versatile serine protease and enable the future development of potentially more efficient anticoagulant APC variants for treatments of thrombotic diseases.

\section{Key words}

Activated protein C, Serine protease, Zinc, Blood coagulation, Enzyme inhibition 
Introduction

Activated protein $\mathrm{C}$ (APC) is a $\sim 60 \mathrm{kDa}$ blood plasma glycoprotein, which functions as an important vitamin K-dependent serine protease down-regulating blood coagulation (1). The structure consists of four domains, an N-terminal $\gamma$-carboxyglutamic acid (Gla) domain that contains nine carboxylated glutamic acids, two epidermal growth factor-like regions (EGF-1 and EGF-2) and a serine protease domain containing the catalytic site residues His57, Asp102 and Ser195 (chymotrypsin numbering) (2). Protein C circulates in blood as an inactive zymogen that is activated via proteolytic cleavage by thrombin bound to thrombomodulin in the presence of the endothelial protein $\mathrm{C}$ receptor (EPCR) (3). APC down-regulates coagulation by degrading coagulation factors Va and VIIIa, the cofactors for factors Xa and IXa, respectively, in enzyme complexes on phospholipid surfaces in the presence of factor $S(2,4)$. In addition to the anticoagulant properties, APC has antiinflammatory, anti-apoptotic and cytoprotective effects, which are dependent on the APCmediated cleavage of the protease-activated receptor PAR-1 in the presence of EPCR, leading to a number of signaling events $(1,3,5,6)$.

The activity of APC is modulated by $\mathrm{Ca}^{2+}$. The nine carboxylated glutamates in the Gla domain are able to bind to $\mathrm{Ca}^{2+}$, which changes the conformation of this domain and thus allows both the inactive and active forms of protein $\mathrm{C}$ to bind to phospholipid membranes. Interactions with phospholipids are required for the enzyme complexes catalyzing the activation of protein $\mathrm{C}$ as well as for those in which APC exerts its proteolytic functions. In addition to the Gla domain, APC has one $\mathrm{Ca}^{2+}$-binding site in the EGF-1 domain and one in the 70-80-loop in the serine protease domain (7-9). The binding of $\mathrm{Ca}^{2+}$ to EGF-1 is required for the biological activity of protein $\mathrm{C}$, and it has been proposed that it is involved in the interaction of the enzyme with other proteins, including factor $\mathrm{S}(9)$. Binding of $\mathrm{Ca}^{2+}$ to the 
$70-80$-loop is accompanied by a conformational change that leads to an $\sim 6 \%$ decrease in tryptophan fluorescence. This interaction is required for the activation of protein $\mathrm{C}$ by the thrombin-thrombomodulin complex, and it also somewhat stabilizes the amidolytic activity of $\operatorname{APC}(8,10)$. A similar enhancement on the amidolytic activity by $\mathrm{Mn}^{2+}$ ions has been observed. This effect is believed to be mediated via the $\mathrm{Ca}^{2+}$ binding site in the serine protease domain of APC (11). The amidolytic activity of APC is also modulated by $\mathrm{Na}^{+}$and it has been suggested that the 221-225 loop in the serine protease domain forms a binding site for this ion (12). A previous report showing that Gla domain-less APC requires $\mathrm{Na}^{+}$for its amidolytic activity in the absence but not in the presence of $\mathrm{Ca}^{2+}$, suggested that an allosteric link between the $\mathrm{Na}^{+}$- and $\mathrm{Ca}^{2+}$-binding loops modulates the structure and function of APC (13).

No metal ions have previously been reported to down-regulate the activity of APC. In the present investigation we found that $\mathrm{Zn}^{2+}$ efficiently inhibits the activity of APC, with both a synthetic peptide and factor Va as substrates. We have therefore characterized the interaction of $\mathrm{Zn}^{2+}$ with the enzyme, and its influence on the kinetics of the amidolytic reaction. $\mathrm{Zn}^{2+}$ binding was accompanied by a $40 \%$ decrease in tryptophan fluorescence, which was used to determine the affinity of APC for $\mathrm{Zn}^{2+}$. Structural comparisons and other data are used to propose reasonable models for how the inhibition might arise. 


\section{Materials and methods}

\section{Proteins}

Human full-length APC and APC lacking the Gla-domain (Des-Gla APC) were purchased from Enzyme Research Laboratories (South Bend, IN, USA). The preparations were $>90 \%$ homogenous in $10 \%$ SDS-PAGE under reducing conditions with the Laemmli system. Both the major and minor bands were subjected to peptide mapping by Maldi-Tof MS as described before (14), verifying that all bands were APC. The active concentrations of the APC preparations, determined by stoichiometric titrations against protein $\mathrm{C}$ inhibitor (PCI) with a known active concentration $(14,15)$, were used throughout this study. Human protein S, human $\alpha$-thrombin, human factor Xa, human prothrombin and bovine factor $\mathrm{V} / \mathrm{Va}$ were purchased from Enzyme Research Laboratories (South Bend, IN, USA). The active concentrations of factor Xa and $\alpha$-thrombin were determined as described previously (14, 16).

\section{Experimental conditions}

Enzyme assays and fluorescence measurements were conducted at $25 \pm 0.2^{\circ} \mathrm{C}$ and $\mathrm{pH} 7.4$ in $20 \mathrm{mM}$ Tris- $\mathrm{HCl}$ buffer containing $0.1 \mathrm{M} \mathrm{NaCl}, 0.1 \%$ PEG 8000, except assays containing phospholipid vesicles, for which the PEG was excluded. If indicated, various concentrations of EDTA or a divalent cation as a chloride or sulfate salt were added. The salts used were PA grade from Merck. Unless noted otherwise, all $\mathrm{Zn}^{2+}$ was added as $\mathrm{ZnCl}_{2}$. The water used in buffers had first been purified by the central water purification system at the Uppsala Biomedical Center, followed by purification in a Milli-Q instrument (Millipore), and had a resistance of $18.2 \mathrm{mega} \mathrm{Ohm} / \mathrm{cm}$. 


\section{Chromogenic assays for APC, thrombin and factor Xa activity}

The amidolytic activity of APC was measured spectrophotometrically in a Hitachi U-2000 dual-beam spectrophotometer with the chromogenic peptide substrate L-pyroglutamyl-Lprolyl-L-arginine-p-nitroaniline hydrochloride (S-2366 from Haemochrom Diagnostica, Mölndal, Sweden). The increase in absorbance due to product formation was monitored for 60 seconds at $405 \mathrm{~nm}$. For APC activity, all preincubations were done with at least $100 \mathrm{nM}$ APC, a concentration at which the enzyme was stable under the conditions used. The enzyme was then diluted to $1-2 \mathrm{nM}$ in buffer containing S-2366 at the start of the measurement. The activities of thrombin and factor Xa were measured by similar assays but with the use of the chromogenic peptide substrates S-2238 and S-2222, respectively (Haemochrom Diagnostica, Mölndal, Sweden), as described before $(14,16)$.

\section{Kinetics of APC activity in the presence of $\mathrm{Zn}^{2+}$}

The effects of $\mathrm{Zn}^{2+}$ on $K_{\mathrm{M}}$ and $k_{\text {cat }}$ for the amidolytic activity of APC were determined by measuring APC activity by the chromogenic assay in the presence of either $10 \mu \mathrm{M} \mathrm{Zn}{ }^{2+}, 100$ $\mu \mathrm{M}$ EDTA, $2.5 \mathrm{mM} \mathrm{Ca}^{2+}$ or $2.5 \mathrm{mM} \mathrm{Ca}^{2+}$ and $15 \mu \mathrm{M} \mathrm{Zn}^{2+}$ at $\mathrm{S}-2366$ substrate concentrations varying from 0-3 $\mathrm{mM}$. The somewhat higher zinc concentration used in the presence than in the absence of $\mathrm{Ca}^{2+}$ was choosen due to the $K_{\mathrm{D}}$ for $\mathrm{Zn}^{2+}$ being somewhat higher in the presence than in the absence of $\mathrm{Ca}^{2+}$ (see below). $\mathrm{Zn}^{2+}$ was added to APC at least 2 min before each measurement to ensure that equilibrium was reached. The data were analyzed by nonlinear regression fitting to the Michaelis-Menten equation to give $K_{\mathrm{M}}$ and $k_{\text {cat }}$.

The apparent inhibition constant, $K_{\mathrm{I}}$, for the inhibition of APC by the ion was measured at $\mathrm{Zn}^{2+}$ concentrations varying from $0-100 \mu \mathrm{M}$ and a constant substrate concentration of $0.5 \mathrm{mM} . \mathrm{Zn}^{2+}$ was added to APC or des-Gla APC at least 2 min before each measurement. The determination was done both in the absence and presence of $2.5 \mathrm{mM} \mathrm{Ca}^{2+}$ 


\section{Inactivation of factor Va by APC}

The effect of $\mathrm{Zn}^{2+}$ on the activity of APC was also determined with factor Va as a substrate. The time course and the $\mathrm{Zn}^{2+}$ concentration dependence for the inactivation of factor Va was measured by a two-stage assay, essentially as described previously (18). In the first stage, factor Va (2.4 nM) was incubated with APC $(0.2 \mathrm{nM})$ on $25 \mu \mathrm{M}$ PC/PS vesicles in buffer containing $2.5 \mathrm{mM} \mathrm{Ca}^{2+}$ in the presence or absence of $100 \mu \mathrm{M} \mathrm{Zn}^{2+}$ for $1-12 \mathrm{~min}$. Alternatively the time of incubation was fixed at $2 \mathrm{~min}$ and the $\mathrm{Zn}^{2+}$ concentration varied from 0 to $100 \mu \mathrm{M}$, either in the absence or presence of $0.2 \mathrm{nM}$ protein $\mathrm{S}$. In the second stage, the remaining factor Va activity was determined in a prothrombinase assay, in which the factor Va-enhanced rate of prothrombin activation by factor Xa was determined. The incubation mixture from the first stage was diluted 24-fold into the prothrombinase assay, which was carried out for 15 min with $25 \mu \mathrm{M}$ PC/PS vesicles, $0.6 \mu \mathrm{M}$ prothrombin and $1 \mathrm{nM}$ factor $\mathrm{Xa}$ at $25^{\circ} \mathrm{C}$. The remaining activity of factor Va was determined from the decrease of the rate of thrombin generation, as monitored by an amidolytic activity assay with $200 \mu \mathrm{M}$ S2238, with the absorbance measured at $405 \mathrm{~nm}$ in an ELISA reader (Infinite M200 from Tecan or SpectraMax Plus ${ }^{384}$ from MDS Analytical Technologies). All values are the average of at least three independent measurements \pm standard error. 


\section{Fluorescence spectra and fluorescence titrations}

Fluorescence spectra and titrations were measured in a volume of $500 \mu \mathrm{l}$ in $0.5 \times 0.5 \mathrm{~cm}$ quartz cuvettes with magnetic stirring in an SLM 4800S spectrofluorimeter, modernized with Olis electronics and software (Bogart, GA). All fluorescence values reported were corrected for dilution and inner filter effects.

The effect of the interaction of $\mathrm{Zn}^{2+}$ on the fluorescence of APC was analysed by measurements of fluorescence spectra for APC and des-Gla APC. The optimal $\lambda_{\text {ex }}$ was first determined to be $282 \mathrm{~nm}$ by excitation spectra. Emission spectra were subsequently measured from $\lambda_{\text {em }} 300$ to $450 \mathrm{~nm}$ at the optimal $\lambda_{\mathrm{ex}}$ with 2 and $4 \mathrm{~nm}$ excitation and emission bandwidths, respectively. The spectra were measured at 100-200 nM protein concentrations.

Equilibrium binding was studied by fluorescence titrations monitored by the decrease in tryptophan fluorescence accompanying the interaction of $\mathrm{Zn}^{2+}$ with APC. Excitation and emission wavelengths of 282 and $345 \mathrm{~nm}$, respectively, both experimentally determined to give the highest fluorescence, and excitation and emission bandwidths of 2 and $16 \mathrm{~nm}$, respectively, were used. APC concentrations varied between 100 and $500 \mathrm{nM} . K_{\mathrm{D}}$ values were determined by fitting the titration data to the equilibrium binding equation by nonlinear least-squares analysis, as described before, assuming a 1:1 binding stoichiometry (15).

\section{Modeling of $\mathrm{Zn}$ ion into the catalytic module}

Sequences similar to that of APC were located among the protein entries of GenBank (19) and aligned using CLUSTAL W (20). All similar catalytic domain structures were obtained from the Protein Data Bank (PDB) (21), then superimposed and compared with the programs LSQMAN (22) and O (23). O was used to model the zinc ions and the structural figures were prepared using $\mathrm{O}$ and Molray (24). 


\section{Results}

\section{Effects of divalent cations on APC amidolytic activity}

The amidolytic activity of APC was measured spectrophotometrically with the use of the chromogenic peptide substrate S-2366 $(0.5 \mathrm{mM})$ in the presence of either EDTA or one of the metal salts $\mathrm{MnCl}_{2}, \mathrm{MgCl}_{2}, \mathrm{NiCl}_{2}, \mathrm{CuSO}_{4}$, and $\mathrm{ZnCl}_{2}$ (Fig. 1). The effects of all the salts were determined at two concentrations, one corresponding to the physiological concentration of each metal ion in blood (25-28) and one which was the same for all the salts, i.e. $2.5 \mathrm{mM}$. Three of the salts, $\mathrm{NiCl}_{2}, \mathrm{CuSO}_{4}$ and $\mathrm{ZnCl}_{2}$, lowered APC activity in a concentrationdependent manner. Since $\mathrm{Cu}^{2+}, \mathrm{Ni}^{2+}$ and $\mathrm{Zn}^{2+}$ ions have similar sizes $(\sim 0.7-0.75 \AA)$, the same charge and usually similar ligands and coordination, they presumably inhibit APC by similar mechanisms. At physiological concentrations $\mathrm{Zn}^{2+}$ was, however, a more efficient inhibitor than $\mathrm{Cu}^{2+}$ and $\mathrm{Ni}^{2+}$ and reduced APC activity by $\sim 60 \% . \mathrm{Zn}^{2+}$ was chosen for further experiments not only because of this efficiency but also because, in contrast to copper ions, it is not redox reactive, simplifying the interpretation of the data. It should be noted, however, that $\mathrm{Cu}^{2+}$, besides $\mathrm{Zn}^{2+}$, also may have a regulatory effect on APC activity. A similar inhibiting effect was observed when $\mathrm{ZnSO}_{4}$ was used instead of $\mathrm{ZnCl}_{2}$ (not shown), verifying that the metal ion was the inhibiting component in both salts.

\section{Effects of $\mathrm{Zn}^{2+}$ on APC cleavage of S-2366}

The amidolytic activity of APC was studied at different substrate concentrations in the presence of either $100 \mu \mathrm{M}$ EDTA, $10 \mu \mathrm{M} \mathrm{ZnCl}_{2}, 2.5 \mathrm{mM} \mathrm{Ca}^{2+}$ or $2.5 \mathrm{mM} \mathrm{Ca}^{2+}$ and $15 \mu \mathrm{M}$ $\mathrm{Zn}^{2+}$. The $\mathrm{Zn}^{2+}$ concentrations used are in the range of the total physiological $\mathrm{Zn}^{2+}$ concentrations in blood. The plots of APC activity versus the substrate concentration fit well to the Michaelis-Menten equation (Fig. 2A). The $K_{\mathrm{M}}$ value determined in the presence of 
$\mathrm{Zn}^{2+}$ was somewhat lower than that determined in the presence of EDTA (Table 1), demonstrating that the binding of $\mathrm{Zn}^{2+}$ does not decrease the affinity of APC for the substrate. In contrast, $k_{\text {cat }}$ was $\sim 7$-fold decreased, demonstrating that $\mathrm{Zn}^{2+}$ dramatically inhibits the mechanism by which APC cleaves the substrate. In the presence of $2.5 \mathrm{mM} \mathrm{Ca}^{2+}$, $15 \mu \mathrm{M} \mathrm{Zn}{ }^{2+}$ did not induce any significant effect on $K_{\mathrm{M}}$ but reduced $k_{\text {cat }} \sim 2$-fold (Table 1). Thus, $\mathrm{Zn}^{2+}$ inhibited APC by decreasing $k_{\text {cat }}$ both in the absence and presence of $\mathrm{Ca}^{2+}$.

The amidolytic activities of APC and des-Gla APC were also measured at various concentrations of $\mathrm{ZnCl}_{2}$ with $0.5 \mathrm{mM}$ substrate. The plots of the decrease in APC activity versus the increase in $\left[\mathrm{Zn}^{2+}\right]$ fit well to the equation for non-competitive inhibition (Eq. 1) (Fig. 2B) giving $K_{\mathrm{I}}$ values of $13 \pm 2$ and $25 \pm 1 \mu \mathrm{M}$ for APC and des-Gla APC, respectively in the absence of $\mathrm{Ca}^{2+}$ (Table 1). These results demonstrate that the Gla-domain is not of major importance for the inhibitory effect of $\mathrm{Zn}^{2+}$ on APC activity. When the amidolytic activity was measured in the presence of $2.5 \mathrm{mM} \mathrm{Ca}^{2+}$, the $K_{\mathrm{I}}$ value for zinc inhibition of APC was $56 \pm 4 \mu \mathrm{M}$. At saturating concentration of $\mathrm{Zn}^{2+}$, the APC activity was completely abolished.

To compare the effect of $\mathrm{Zn}^{2+}$ on APC activity with that on the activity of procoagulant proteases whose cofactors APC degrades, thrombin and factor Xa activities in the presence of $\mathrm{Zn}^{2+}$ were also measured. Only a slight decrease in the activities of these proteases was observed in the presence of $\mathrm{Zn}^{2+}$. The decreases in thrombin and factor $\mathrm{Xa}$ activities were $\sim 40 \%$ at $2.5 \mathrm{mM} \mathrm{Zn}^{2+}$, corresponding to $K_{\mathrm{I}}$ values of over $5 \mathrm{mM}$. The concentrations of $\mathrm{Zn}^{2+}$ required for the inhibition of thrombin and factor $\mathrm{Xa}$ are thus at least two orders of magnitude higher than those required for the inhibition of APC.

The reversibility of the inhibitory effect of $\mathrm{Zn}^{2+}$ on APC activity was determined by adding $20 \mu \mathrm{M}$ EDTA to an APC solution containing $10 \mu \mathrm{M} \mathrm{Zn}^{2+}$. After the addition of 10 $\mu \mathrm{M} \mathrm{Zn}{ }^{2+}$, the activity was $59 \pm 1 \%$ of the control value and after further addition of EDTA, 


\section{Effects of $\mathrm{Zn}^{2+}$ on the inactivation of factor Va by APC}

The effects of zinc ions on the inactivation of factor Va by APC were determined by a twostage assay. In the first stage, factor Va was incubated with APC in the presence of phospholipid vesicles and physiological $\mathrm{Ca}^{2+}$ concentration for various time-points with or

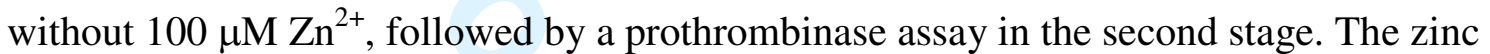
concentration used was calculated to result in $~ 83 \%$ saturation of the APC $(0.2 \mathrm{nM})$ used in this assay, based on the apparent affinity of APC for $\mathrm{Zn}^{2+}$ in the presence of $\mathrm{Ca}^{2+}$. The activity in the prothrombinase assay as a function of the time of incubation of factor $\mathrm{Va}$ and APC in the absence or presence of $\mathrm{Zn}^{2+}$ is shown in Figure 3A. The activity decreased much more rapidly in the absence than in the presence of $\mathrm{Zn}^{2+}$, demonstrating that this ion significantly lowered the ability of APC to inactivate factor Va.

The influence of the $\mathrm{Zn}^{2+}$ concentration on the inactivation of factor Va was studied by a similar two-stage assay as described above but with varying concentrations of $\mathrm{Zn}^{2+}$ and a fixed incubation time of $2 \mathrm{~min}$. This experiment was done in the absence or presence of equimolar concentration of the cofactor for APC, protein S. In the absence of factor S, the amount of thrombin generated, reflecting the inhibition of APC activity, increased dosedependently in a hyperbolic manner from $0-100 \mu \mathrm{M} \mathrm{Zn}^{2+}$ (Fig. 3B). The inhibitory effect of zinc ions was also observed in the presence of the cofactor, although with a shift toward somewhat higher $\mathrm{Zn}^{2+}$ concentrations and a different shape of the $\mathrm{Zn}^{2+}$-concentration dependency. This finding may be partially explained by the previous observation that commercial protein $\mathrm{S}$ preparations contain very little $\mathrm{Zn}^{2+}$, in contrast to human protein $\mathrm{S}$ 
purified by immunoaffinity chromatography, which contains the $\mathrm{Zn}^{2+}$-bound form of the protein (29). A small portion of the $\mathrm{Zn}^{2+}$ used in our assay may thus have been consumed by protein $\mathrm{S}$ to retain the $\mathrm{Zn}^{2+}$-bound form of the protein. The concentration of protein $\mathrm{S}$ was, however, very small compared to that of $\mathrm{Zn}^{2+}$. Another potential explanation may thus be that the $\mathrm{Zn}^{2+}$-binding site is slightly less exposed when APC is bound to protein $\mathrm{S}$.

\section{Effects of $\mathrm{Zn}^{2+}$ on tryptophan fluorescence spectra}

The effect of the interaction with $\mathrm{Zn}^{2+}$ on the fluorescence of APC and des-Gla APC was assessed by measurements of tryptophan fluorescence emission spectra for APC and des-Gla APC (Fig. 4A \& B). The maximal emission was at $345 \mathrm{~nm}$ for both proteins. The addition of $500 \mu \mathrm{M} \mathrm{Zn}^{2+}$ to $200 \mathrm{nM}$ APC, calculated to give $\sim 98 \%$ saturation based on the $K_{\mathrm{D}}$ determined below, resulted in $\sim 40$ and $30 \%$ decreases in the fluorescence intensity at $345 \mathrm{~nm}$, for APC and des-Gla APC, respectively. The wavelength of the fluorescence emission maximum was not affected by the interaction with $\mathrm{Zn}^{2+}$.

The reversibility of $\mathrm{Zn}^{2+}$-binding to APC was evaluated by measuring tryptophan fluorescence emission spectra before and after the addition of $200 \mu \mathrm{M}$ EDTA to $200 \mathrm{nM}$ APC containing $100 \mu \mathrm{M} \mathrm{ZnCl}_{2}$ (Fig. 4C). These concentrations of APC and $\mathrm{Zn}^{2+}$ were estimated to result in $\sim 93 \%$ of saturation of APC. The addition of $200 \mu \mathrm{M}$ EDTA to APC in the absence of $\mathrm{Zn}^{2+}$ resulted in a small decrease in fluorescence, presumably due to EDTA quenching the tryptophan fluorescence of APC. The addition of $100 \mu \mathrm{M} \mathrm{ZnCl}_{2}$ to $200 \mathrm{nM}$ APC lowered the fluorescence of APC, as estimated, and after further addition of $200 \mu \mathrm{M}$ EDTA to this solution, the fluorescence was restored to that of APC containing EDTA but not $\mathrm{Zn}^{2+}$ (Fig. 4C). These findings show that the decrease in fluorescence caused by the interaction of $\mathrm{Zn}^{2+}$ with APC is fully reversible. Similar results were obtained when the reversibility of the $\mathrm{Zn}^{2+}$-induced decrease in fluorescence of des-GLA APC was studied. 


\section{Binding affinities determined by fluorescence}

The decrease in fluorescence caused by $\mathrm{Zn}^{2+}$ binding to APC was used to determine apparent $K_{\mathrm{D}}$ values from fluorescence titration curves. The relatively weak binding affinity precluded assessment of binding stoichiometry. The data were well fitted to the equilibrium binding equation (15) with the assumption of an equimolar binding stoichiometry (Fig. 5). $K_{\mathrm{D}}$ values were 7.4 \pm 1.5 and $19 \pm 3 \mu \mathrm{M}$ (Table 1) for the interactions of $\mathrm{Zn}^{2+}$ with APC and des-Gla APC, respectively, in the absence of $\mathrm{Ca}^{2+}$. In the presence of $2.5 \mathrm{mM} \mathrm{Ca}^{2+}$ the $K_{\mathrm{D}}$ value was $20 \pm 3$ $\mu \mathrm{M}$ for the interaction of $\mathrm{Zn}^{2+}$ with APC.

\section{Discussion}

An initial finding in our laboratory that the amidolytic activity of APC was abolished in the presence of $\mathrm{Zn}^{2+}$ initiated this investigation, in which we have characterized the interaction of $\mathrm{Zn}^{2+}$ with APC and quantified the inhibitory effect of $\mathrm{Zn}^{2+}$ on APC activity. The unaffected or somewhat decreased $K_{\mathrm{M}}$ and 7-fold decreased $k_{\text {cat }}$, determined by varying the concentrations of a chromogenic peptide substrate at a zinc concentration of $10 \mu \mathrm{M}$, demonstrated that $\mathrm{Zn}^{2+}$ inhibited APC by a non-competitive mechanism. These results suggest that metal binds at a position distinct from the active site and that a conformational change of APC is involved in generating a catalytically inert form of the protease. Such a 
conformational change was also supported by the $\sim 40 \%$ decrease in tryptophan fluorescence induced by the binding of $\mathrm{Zn}^{2+}$ to APC. The agreement between the $K_{\mathrm{D}}$ determined by fluorescence and the $K_{\mathrm{I}}$ determined by a chromogenic assay, support that $\mathrm{Zn}^{2+}$-binding results in the inhibition of the enzymatic activity. The 3-4-fold higher $K_{\mathrm{D}}$ and $K_{\mathrm{I}}$ values in the presence than in the absence of physiological $\mathrm{Ca}^{2+}$ concentration showed that $\mathrm{Ca}^{2+}$ affected the affinity of APC for $\mathrm{Zn}^{2+}$. Nevertheless the inhibition of APC by $\mathrm{Zn}^{2+}$ was still noncompetitive in the presence of $\mathrm{Ca}^{2+}$, as demonstrated by the unaffected $K_{\mathrm{M}}$ and decreased $k_{\text {cat }}$. The catalytic machinery was inhibited by zinc ions both using a chromogenic peptide substrate, and in a more physiological assay based on the degradation of factor Va by APC in the presence of phospholipid vesicles and physiological $\mathrm{Ca}^{2+}$ concentration. These results thus support a role of zinc ions in regulating the anticoagulant activity of APC.

The $K_{\mathrm{I}}$ in the low micromolar range, comparable to the concentrations of zinc ions found in blood plasma and platelets, suggests that the inhibition of APC by these ions may be physiologically relevant. The total concentration of zinc ions in blood plasma is $\sim 15-20 \mu \mathrm{M}$, whereas the concentration of free zinc is only around $0.15-0.5 \mu \mathrm{M}$, because the majority of these ions in blood are bound to proteins (31-33). Zinc ions are, however, enriched in platelets at a total concentration of approximately $500 \mu \mathrm{M}$, distributed between the $\alpha$ granules and cytoplasm (33). Several previous studies have shown that zinc ions are released during platelet activation and it has been proposed that such release leads to a local increase in the concentration of $\mathrm{Zn}^{2+}$ at the platelet surface (34-37). The exact concentration of $\mathrm{Zn}^{2+}$ at this surface is difficult to estimate. Blood coagulation is, however, known to be very local and restrictive. Since the surface of the activated platelet is a potential site of action of APC, due to the presence of factors Va and VIIIa of the tenase and prothrombinase complexes, respectively, it is highly possible that the activity of APC is down-regulated by $\mathrm{Zn}^{2+}$ on this surface. The $\mathrm{Zn}^{2+}$-concentration dependence for the inactivation of factor Va by APC 
determined in this study was clearly dose-dependent in a hyperbolic manner from $0-100 \mu \mathrm{M}$ $\mathrm{Zn}^{2+}$, but was somewhat shifted to higher $\mathrm{Zn}^{2+}$ concentration in the presence of factor $\mathrm{S}$. This latter finding may relate to the need for protection against $\mathrm{Zn}^{2+}$ inhibition in situations where anticoagulation is needed. The more than two orders of magnitude higher $K_{\mathrm{I}}$ values for the inhibition of factor Xa and thrombin by $\mathrm{Zn}^{2+}$ than for the inhibition of APC supports the conclusion that $\mathrm{Zn}^{2+}$ may regulate APC activity. In further support of this conclusion, it has been shown that APC inactivates factor Va much more efficiently on artificial phospholipid membranes or endothelial cells than on platelets (38). $\mathrm{Cu}^{2+}$ ions, which are also found in platelets, may contribute to such effect (39).

The inhibitory effect of $\mathrm{Zn}^{2+}$ on APC activity described here is in line with the overall procoagulant effect of $\mathrm{Zn}^{2+}$, which has recently been reviewed (31). Deficiency of $\mathrm{Zn}^{2+}$ in the diet results in a decrease in the concentration of $\mathrm{Zn}^{2+}$ in blood and, as a consequence, leads to a tendency for clotting disturbances (40). For instance, the ion induces platelet aggregation and fibrin clot formation $(40,41)$. Moreover, $\mathrm{Zn}^{2+}$ has been proposed to lower the anticoagulant action of antithrombin, by enhancing the binding affinity of histidine-rich glycoprotein for heparin and thus neutralizing the anticoagulant activity of heparin in plasma (37). Apart from blood, protein $\mathrm{C}$ is expressed in several other tissues (http://www.proteinatlas.org). Another potential physiological role for $\mathrm{Zn}^{2+}$ inhibition of APC may thus be to prevent unwanted proteolytic activities in such tissues where the concentrations of zinc ions are high, including the reproductive system and various parts of the central nervous system, such as the hippocampus (32).

Interestingly, two of the proteins that APC interacts with have already been identified as $\mathrm{Zn}^{2+}$ binders. It was recently discovered that plasma protein $\mathrm{S}$ contains $\mathrm{Zn}^{2+}$ and that this ion is essential for the APC-independent anticoagulant activity of protein S (29). The finding that the $\mathrm{Zn}^{2+}$-content in protein $\mathrm{S}$ preparations does not influence the APC-dependent 
anticoagulant activity of protein S (29) is in line with our observation that the inhibitory effect of $\mathrm{Zn}^{2+}$ on APC anticoagulant activity is caused by the ion binding to APC. Earlier it was shown that $\alpha_{2}$-macroglobulin is a $\mathrm{Zn}^{2+}$-binding protein in blood (32). Additionally, other serine proteases involved in the regulation of blood coagulation are affected by $\mathrm{Zn}^{2+}$, including factor XII, factor XI and factor VIIa(31). For factor VIIa, the catalytic machinery is inhibited by $\mathrm{Zn}^{2+}$ ions, as for APC. Two $\mathrm{Zn}^{2+}$ sites have been proposed in factor VIIa that are distal from the catalytic site but overlap the $\mathrm{Ca}^{2+}$ binding site (42). The functional consequence of the inhibitory effects of zinc ions on factor VIIa activity are, however, opposite to those on APC activity, since factor VIIa functions as a procoagulant in the presence of tissue factor. For APC, a procoagulant effect exerted by $\mathrm{Zn}^{2+}$ seems straightforward to explain from a functional point of view, assuming that such inhibition occurs at sites of injury where platelets accumulate and coagulation is required to prevent the loss of blood. In contrast, the anticoagulant effects induced by the interaction of $\mathrm{Zn}^{2+}$ with protein S and factor VIIa would make sense only if they occur at sites where coagulation is not wanted, such as the healthy endothelium. Future investigations are required to clarify the physiological functions of all these $\mathrm{Zn}^{2+}$-protein interactions

The inhibitory effect of $\mathrm{Zn}^{2+}$ on APC activity may be contrasted with the activation of the enzyme by $\mathrm{Ca}^{2+}(7,8,10)$, which raised the question of whether $\mathrm{Zn}^{2+}$ merely displaces $\mathrm{Ca}^{2+}$ from its binding site, as for factor VIIa. This possibility could, however, be excluded for several reasons. We have shown that the interaction of $\mathrm{Zn}^{2+}$ with APC is reversible, along with the fluorescence change induced by the interaction of $\mathrm{Zn}^{2+}$ with APC. The decrease in fluorescence induced by $\mathrm{Ca}^{2+}$-binding to APC is only $\sim 6 \%$ whereas the decrease in fluorescence induced by $\mathrm{Zn}^{2+}$ binding is $\sim 40 \%$. Thus, if $\mathrm{Zn}^{2+}$ was binding to the $\mathrm{Ca}^{2+}$-binding site, an increase in fluorescence should be observed when excessive amounts of $\mathrm{Ca}^{2+}$ are added to $\mathrm{Zn}^{2+}$-bound APC. This does not happen. Moreover, the greater effect on the intrinsic 
fluorescence of APC induced by $\mathrm{Zn}^{2+}$ than by $\mathrm{Ca}^{2+}(8,30)$ indicates that the two metal ions induce different conformational changes in APC. Finally, $\mathrm{Zn}^{2+}$ was able to completely abolish the amidolytic activity of APC, whereas $\mathrm{Ca}^{2+}$ somewhat stabilizes but is not required for the amidolytic activity of the enzyme (8). Since the $K_{\mathrm{I}}$ and $K_{\mathrm{D}}$ values observed for the interaction of $\mathrm{Zn}^{2+}$ with APC were 3-4-fold higher in the presence than in the absence of $\mathrm{Ca}^{2+}$, it thus appears as if the $\mathrm{Zn}^{2+}$-binding site is affected by the conformational change induced by $\mathrm{Ca}^{2+}$. The similar influence of $\mathrm{Zn}^{2+}$ on des-Gla APC and full-length APC demonstrated that the $\mathrm{Zn}^{2+}$-binding site is not located in the Gla domain, which contains several $\mathrm{Ca}^{2+}$-binding sites. Together, these findings suggest that $\mathrm{Zn}^{2+}$ binds to a site that is distinct from the $\mathrm{Ca}^{2+}$ binding site in the 70-80 loop, but located, at least partially, in the serine protease domain.

To identify potential $\mathrm{Zn}^{2+}$-binding sites, we sought appropriate residues (histidine, cysteine, aspartate and glutamate, accounting for $97 \%$ of amino acids in $\mathrm{Zn}^{2+}$ sites) (43) that are clustered in the structure of human APC or could be envisioned to be close after conformational changes. A careful consideration of PDB entry 1AUT (44) indicated several potential sites. The simplest possibility is illustrated in Fig. 6A \& B. The structure of an engineered trypsin mutant with a $21 \mu \mathrm{M} K_{\mathrm{D}}$ for $\mathrm{Cu}^{2+}$ has been reported elsewhere (45), showing that the equivalent of His57 can assume a different conformation, allowing it to form part of an ion binding site. A similar motion of the charge-relay histidine was reported still earlier for $\mathrm{Zn}^{2+}$ binding in the tonin structure (46). In APC, possible zinc binding residues close to His57 include Asp60 and Glu60A. Since this histidine is an essential component of the catalytic triad, a change in conformation would render the enzyme inactive; this could easily occur without disrupting substrate binding, and so $K_{\mathrm{M}}$. However, the large change in tryptophan fluorescence of $\mathrm{APC}$ on $\mathrm{Zn}^{2+}$ binding suggests that additional, more extensive conformational changes also occur. Looking for conserved residues in APC, we 
found two clusters that are also candidates for ion-binding sites. One of these includes His48, Ser50, His107 and Trp51, as modeled in Fig. 6C. It is not clear whether the interaction of $\mathrm{Zn}^{2+}$ with these residues would affect the catalytic machinery. His91, His241 and Trp237 comprise another cluster, but since the latter residues are also present in other blood clotting proteases, they are not likely to give an effect specific for APC. These sites, however, include residues less commonly involved in $\mathrm{Zn}^{2+}$ binding. A potential $\mathrm{Zn}^{2+}$ site includes residues in the 144-153 loop, i.e. His144/Glu148/Glu149A, and possibly Asp18. The loop is an insertion in APC relative to other sequences, but the proposed $\mathrm{Zn}^{2+}$-binding residues are not as strongly conserved in mammalian APC sequences as one would expect if the function is widespread. In this model, an extensive conformational change would be required to convey the information to the active site. Clearly, a number of structural, mutational and other studies will be required to understand the basis of zinc binding and inhibition.

The ability of $\mathrm{Zn}^{2+}$ to inhibit the amidolytic activity of APC is a highly interesting finding that broadens our understanding of the physiological function of this versatile serine protease, which is capable of inhibiting blood coagulation as well as inflammation and apoptosis. Furthermore, it is medically interesting from several points of view. APC is used clinically to treat patients with severe sepsis (47) and has the potential to be used in future treatments of several additional thrombotic and/or inflammatory diseases, including stroke (48), multiple sclerosis (49) and diabetic endothelial and glomerular injury (50). Knowledge about the $\mathrm{Zn}^{2+}$-binding site may therefore be used to produce specialized recombinant forms of APC that are resistant to inhibition by $\mathrm{Zn}^{2+}$. Such engineering could be combined with other tailor-made structural features of the enzyme to give a potentially improved therapeutic effect. 


\section{Acknowledgements}

The authors thank Professor Ingemar Björk for helpful discussions and for commenting on the manuscript. 


\section{References}

1. Griffin JH, Fernandez JA, Gale AJ, et al. Activated protein C. J Thromb Haemost 2007; $1: 73-80$.

2. Hansson K, Stenflo J. Post-translational modifications in proteins involved in blood coagulation. J Thromb Haemost 2005; 3: 2633-48.

3. Dahlbäck B, Villoutreix BO. Regulation of blood coagulation by the protein C anticoagulant pathway: novel insights into structure-function relationships and molecular recognition. Arterioscler Thromb Vasc Biol 2005; 25:1311-20.

4. Esmon CT. The roles of protein $\mathrm{C}$ and thrombomodulin in the regulation of blood coagulation. J Biol Chem 1989; 264: 4743-6.

5. Bae JS, Rezaie AR. Protease activated receptor 1 (PAR-1) activation by thrombin is protective in human pulmonary artery endothelial cells if endothelial protein $\mathrm{C}$ receptor is occupied by its natural ligand. Thrombosis and haemostasis 2008; 100: 101-9.

6. Bae JS, Rezaie AR. Thrombin inhibits nuclear factor kappaB and RhoA pathways in cytokine-stimulated vascular endothelial cells when EPCR is occupied by protein C.

Thrombosis and haemostasis 2009; 101: 513-20.

7. Johnson AE, Esmon NL, Laue TM, et al. Structural changes required for activation of protein $\mathrm{C}$ are induced by $\mathrm{Ca} 2+$ binding to a high affinity site that does not contain gammacarboxyglutamic acid. J Biol Chem 1983; 258: 5554-60.

8. Rezaie AR, Mather T, Sussman F, et al. Mutation of Glu-80-->Lys results in a protein $\mathrm{C}$ mutant that no longer requires $\mathrm{Ca} 2+$ for rapid activation by the thrombin-thrombomodulin complex. J Biol Chem 1994; 269: 3151-4. 
9. Ohlin AK, Landes G, Bourdon P, et al. Beta-hydroxyaspartic acid in the first epidermal growth factor-like domain of protein $\mathrm{C}$. Its role in $\mathrm{Ca} 2+$ binding and biological activity. J Biol Chem 1988; 263: 19240-8.

10. Yang L, Rezaie AR. Calcium-binding sites of the thrombin-thrombomodulin-protein C complex: possible implications for the effect of platelet factor 4 on the activation of vitamin K-dependent coagulation factors. Thromb Haemost 2007; 97: 899-906.

11. Hill KA, Castellino FJ. The binding of Mn2+ to bovine plasma protein C, des(1-41)light chain protein $\mathrm{C}$, and activated des(1-41)-light chain activated protein C. Arch Biochem Biophys 1987; 254: 196-202.

12. Steiner SA, Castellino FJ. Kinetic studies of the role of monovalent cations in the amidolytic activity of activated bovine plasma protein C. Biochemistry; 21: 4609-14.

13. He X, Rezaie AR. Identification and characterization of the sodium-binding site of activated protein C. J Biol Chem 1999; 274: 4970-6.

14. Sun W, Parry S, Panico M, et al. N-glycans and the $\mathrm{N}$ terminus of protein $\mathrm{C}$ inhibitor affect the cofactor-enhanced rates of thrombin inhibition. J Biol Chem 2008; 283: 18601-11. 15. Olson ST, Björk I, Shore JD. Kinetic characterization of heparin-catalyzed and uncatalyzed inhibition of blood coagulation proteinases by antithrombin. Methods Enzymol 1993; 222: 525-59.

16. Sun W, Eriksson AS, Schedin-Weiss S. Heparin enhances the inhibition of factor Xa by protein $\mathrm{C}$ inhibitor in the presence but not in the absence of $\mathrm{Ca}(2+)$. Biochemistry 2009; 48: $1094-8$.

17. Knight CG. The characterization of enzyme inhibition. In: Proteinase inhibitors. Elsevier, Oxford, Amsterdam 1986: 23-51. 
18. Gale AJ, Heeb MJ, Griffin JH. The autolysis loop of activated protein C interacts with factor Va and differentiates between the Arg506 and Arg306 cleavage sites. Blood 2000; 96: 585-93.

19. Benson DA, Karsch-Mizrachi I, Lipman DJ, et al. GenBank. Nucleic Acids Res 2008; 36: D25-30.

20. Thompson JD, Higgins DG, Gibson TJ. CLUSTAL W: improving the sensitivity of progressive multiple sequence alignment through sequence weighting, position-specific gap penalties and weight matrix choice. Nucleic Acids Res 1994; 22: 4673-80.

21. Berman HM, Westbrook J, Feng Z, et al. The Protein Data Bank. Nucleic Acids Res 2000; $28: 235-42$.

22. Kleywegt GJ. Use of non-crystallographic symmetry in protein structure refinement. Acta Crystallogr D Biol Crystallogr 1996; 52: 842-57.

23. Jones TA, Zou JY, Cowan SW, et al. Improved methods for building protein models in electron density maps and the location of errors in these models. Acta Crystallogr A 1991; 47: 110-9.

24. Harris M, Jones TA. Molray--a web interface between $\mathrm{O}$ and the POV-Ray ray tracer. Acta Crystallogr D Biol Crystallogr 2001; 57: 1201-3.

25. Christensen JM, Kristiansen J, Nielsen NH, et al. Nickel concentrations in serum and urine of patients with nickel eczema. Toxicol Lett 1999; 108: 185-9.

26. Zoppi F, De Gasperi A, Guagnellini E, et al. Measurement of ionized magnesium with AVL 988/4 electrolyte analyzer: preliminary analytical and clinical results. Scand J Clin Lab Invest Suppl 1996; 224: 259-74.

27. Fell JM, Reynolds AP, Meadows N, et al. Manganese toxicity in children receiving long-term parenteral nutrition. Lancet 1996; 347: 1218-21. 
28. Kassu A, Yabutani T, Mahmud ZH, et al. Alterations in serum levels of trace elements in tuberculosis and HIV infections. Eur J Clin Nutr 2006; 60: 580-6.

29. Heeb MJ, Prashun D, Griffin JH, et al. Plasma protein S contains zinc essential for efficient activated protein $\mathrm{C}$-independent anticoagulant activity and binding to factor $\mathrm{Xa}$, but not for efficient binding to tissue factor pathway inhibitor. Faseb J 2009; 23: 2244-53.

30. Sugo T, Bjork I, Holmgren A, et al. Calcium-binding properties of bovine factor X lacking the gamma-carboxyglutamic acid-containing region. J Biol Chem 1984; 259: 570510.

31. Tubek S, Grzanka P, Tubek I. Role of zinc in hemostasis: a review. Biol Trace Elem Res 2008; 121: 1-8.

32. Vallee BL, Falchuk KH. The biochemical basis of zinc physiology. Physiol Rev 1993; 73: 79-118.

33. Gorodetsky R, Mou X, Blankenfeld A, et al. Platelet multielemental composition, lability, and subcellular localization. Am J Hematol 1993; 42: 278-83.

34. Aktulga A, Ulutin ON. Normal human platelet zinc content and its release. In: Platelets Recent advances in basic research and clinical aspects. American Elsevier Publishing Co Inc, New York 1976: 185-91.

35. Mahdi F, Madar ZS, Figueroa CD, et al. Factor XII interacts with the multiprotein assembly of urokinase plasminogen activator receptor, $\mathrm{gC} 1 \mathrm{qR}$, and cytokeratin 1 on endothelial cell membranes. Blood 2002; 99: 3585-96.

36. Foley B, Johnson SA, Hackley B, et al. Zinc content of human platelets. Proceedings of the Society for Experimental Biology and Medicine Society for Experimental Biology and Medicine (New York, NY) 1968 ; 128: 265-9.

37. Kluszynski BA, Kim C, Faulk WP. Zinc as a cofactor for heparin neutralization by histidine-rich glycoprotein. J Biol Chem 1997; 272: 13541-7. 
38. Roberts HR, Hoffman M, Monroe DM. A cell-based model of thrombin generation. Semin Thromb Hemost 2006; 32 Suppl 1: 32-8.

39. Kiem J, Borberg H, Iyengar GV, et al. Elemental composition of platelets. Part II. Water content of normal human platelets and measurements of their concentrations of $\mathrm{Cu}, \mathrm{Fe}$, $\mathrm{K}$, and Zn by neutron activation analysis. Clinical chemistry 1979; 25: 705-10.

40. Gordon PR, Woodruff CW, Anderson HL, et al. Effect of acute zinc deprivation on plasma zinc and platelet aggregation in adult males. Am J Clin Nutr 1982; 35: 113-9.

41. Marx G, Eldor A. The procoagulant effect of zinc on fibrin clot formation. Am $\mathbf{J}$ Hematol 1985; 19: 151-9.

42. Bajaj SP, Schmidt AE, Agah S, et al. High resolution structures of paminobenzamidine- and benzamidine-VIIa/soluble tissue factor: unpredicted conformation of the 192-193 peptide bond and mapping of $\mathrm{Ca} 2+, \mathrm{Mg} 2+, \mathrm{Na}+$, and $\mathrm{Zn} 2+$ sites in factor VIIa. $\mathrm{J}$ Biol Chem 2006; 281: 24873-88.

43. Tamames B, Sousa SF, Tamames J, et al. Analysis of zinc-ligand bond lengths in metalloproteins: trends and patterns. Proteins 2007; 69: 466-75.

44. Mather T, Oganessyan V, Hof P, et al. The 2.8 A crystal structure of Gla-domainless activated protein C. Embo J 1996; 15: 6822-31.

45. McGrath ME, Haymore BL, Summers NL, et al. Structure of an engineered, metalactuated switch in trypsin. Biochemistry 1993; 32: 1914-9.

46. Fujinaga M, James MN. Rat submaxillary gland serine protease, tonin. Structure solution and refinement at 1.8 A resolution. J Mol Biol 1987; 195: 373-96.

47. Toltl LJ, Swystun LL, Pepler L, et al. Protective effects of activated protein C in sepsis. Thrombosis and haemostasis 2008; 100: 582-92.

48. Zlokovic BV, Zhang C, Liu D, et al. Functional recovery after embolic stroke in rodents by activated protein C. Ann Neurol 2005; 58: 474-7. 
49. Han MH, Hwang SI, Roy DB, et al. Proteomic analysis of active multiple sclerosis lesions reveals therapeutic targets. Nature 2008 Feb; 451: 1076-81.

50. Isermann B, Vinnikov IA, Madhusudhan T, et al. Activated protein C protects against diabetic nephropathy by inhibiting endothelial and podocyte apoptosis. Nat Med 2007; 13: 1349-58. 


\section{Figure legends}

Figure 1. Effects of metal ions on the amidolytic activity of APC. APC activity was measured spectrophotometrically with the use of the chromogenic peptide substrate, S-2366, as described in Materials and methods. The activity of APC measured in $100 \mu \mathrm{M}$ EDTA in the absence of metal ion was used as a control and was set to $100 \%$ activity. The values are the means \pm SE of two measurements.

\section{Figure 2. Amidolytic activity of APC and des-GLA APC measured}

spectrophotometrically with the substrate S-2366. (A) The influence of substrate concentration on the rate of substrate hydrolysis by APC was determined in the presence of $100 \mu \mathrm{M} \operatorname{EDTA}(\bigcirc), 10 \mu \mathrm{M} \mathrm{Zn}^{2+}(\bigcirc), 2.5 \mathrm{mM} \mathrm{Ca}^{2+}(\square)$ or $15 \mu \mathrm{M} \mathrm{Zn}^{2+}$ and $2.5 \mathrm{mM}$ $\mathrm{Ca}^{2+}(\boldsymbol{\square})$. Solid lines represent nonlinear regression fitting to the Michaelis-Menten equation. (B) The influence of the concentration of $\mathrm{Zn}^{2+}$ at $0.5 \mathrm{mM} \mathrm{S}-2366$ on the amidolytic activity of APC in the absence $(\bigcirc)$ and presence $(\square)$ of $2.5 \mathrm{mM} \mathrm{Ca}^{2+}$ and of des-Gla APC in the absence of $2.5 \mathrm{mM} \mathrm{Ca}^{2+}(-)$ is shown. Solid lines represent nonlinear regression fitting to the equation for non-competitive inhibition to give the inhibitor constant, $K_{\mathrm{I}}$ (Eq. 1) (17).

\section{Figure 3. Influence of zinc ions on the inactivation of factor Va by APC}

(A) Factor Va was incubated with APC in the presence of phospholipid vesicles and $\mathrm{Ca}^{2+}$ for various time points in the absence $(\boldsymbol{\Delta})$ or presence $(\triangle)$ of $100 \mu \mathrm{M} \mathrm{Zn}^{2+}$, followed by the determination of the remaining activity in a prothrombinase assay, as described in Materials and methods. All values are the means \pm SE of at least three measurements. The amount of thrombin generated in the absence of APC was set to $100 \%$. The solid lines represent nonlinear regression fitting to a biphasic exponential function. (B) Factor Va was incubated 
with APC in the absence $(\nabla)$ or presence $(\boldsymbol{\nabla})$ of protein S. The assay, containing phospholipid vesicles and $\mathrm{Ca}^{2+}$, was run for 2 min at various $\mathrm{Zn}^{2+}$ concentrations, followed by the determination of the remaining activity in a prothrombinase assay, as described in Materials and methods. For each curve, the increase in the activity of thrombin generated is expressed as $\%$ increase related to that generated in the absence of $\mathrm{Zn}^{2+}$. The solid line for data collected in the absence of protein $\mathrm{S}$ represents nonlinear regression fitting to a hyperbolic binding equation. The values are the means $\pm \mathrm{SE}$ of three measurements.

\section{Figure 4. $\mathrm{Zn}^{2+}$-induced changes in tryptophan fluorescence and effects of EDTA.} Uncorrected emission spectra determined at $25^{\circ} \mathrm{C}$ as described in Materials and methods. (A) The effect of $500 \mu \mathrm{M} \mathrm{Zn}^{2+}$ on the fluorescence of $200 \mathrm{nM}$ APC and (B) $200 \mathrm{nM}$ des-GLA APC. (C) Effects of adding $200 \mu \mathrm{M}$ EDTA to $200 \mathrm{nM}$ APC in the absence or presence of 100 $\mu \mathrm{M} \mathrm{Zn^{2+ }}$. Solid black lines, emission spectra of APC or des-Gla APC in the absence of $\mathrm{Zn}^{2+}$ and EDTA; Dotted lines, emission spectra of $\mathrm{Zn}^{2+}$-bound APC or des-Gla APC; Dashed lines, emission spectra of APC containing EDTA; Solid gray lines, emission spectra of EDTA added to $\mathrm{Zn}^{2+}$-bound APC;

\section{Figure 5. Equilibrium binding, studied by tryptophan fluorescence titrations, for the} interaction of $\mathrm{Zn}^{2+}$ with APC and des-Gla APC. Typical fluorescence titrations are shown for the interactions of $\mathrm{Zn}^{2+}$ with APC in the absence $(\bigcirc)$ and presence $(\square)$ of $2.5 \mathrm{mM} \mathrm{Ca}^{2+}$ and des-Gla APC in the absence of $\mathrm{Ca}^{2+}(\mathbf{O})$. The concentrations used of APC and des-GLA APC were $200 \mathrm{nM}$. Solid lines represent nonlinear regression fitting to the equilibrium binding equation (15), assuming a 1:1 binding stoichiometry.

Figure 6. Models of $\mathrm{Zn}^{2+}$ binding to human APC. 
(A) Stereo representations of human APC (PDB entry 1AUT) and anionic trypsin mutant Arg96His (PDB entry 1AND) are shown in red and aquamarine, respectively. The $\mathrm{Cu}^{2+}$ ion in trypsin is shown as a dark green sphere. (B) Model of the binding of $\mathrm{Zn}^{2+}$ (magenta sphere) into the APC active site with only small conformational changes. (C) Model of $\mathrm{Zn}^{2+}$ (yellow sphere) binding to a conserved APC site. 
Table 1. Influence of $\mathrm{Zn}^{2+}$ on the inhibition constant, turnover number and Michaelis constant for the amidolytic activity of APC and affinity of APC for $\mathrm{Zn}^{2+}$. The amidolytic activity of APC was measured spectrophotometrically with the use of the substrate S-2366, as described in Materials and methods. The data from determinations at different substrate concentrations in the presence of either $100 \mu \mathrm{M}$ EDTA, $10 \mu \mathrm{M} \mathrm{Zn}^{2+}, 2.5 \mathrm{mM} \mathrm{Ca}^{2+}$ or $15 \mu \mathrm{M}$ $\mathrm{Zn}^{2+}$ and $2.5 \mathrm{mM} \mathrm{Ca}^{2+}$ were fit to the Michaelis-Menten equation (Fig. 2A) to give the Michaelis constant, $K_{\mathrm{M}}$, and turnover number, $k_{\mathrm{cat}}$. The values \pm SE were obtained by nonlinear regression fitting. Inhibitor constants, $K_{\mathrm{I}}$, are the means \pm SE of 3-4 plots of the amidolytic activity of APC and des-Gla APC versus $\left[\mathrm{Zn}^{2+}\right]$, determined in the absence or presence of $2.5 \mathrm{mM} \mathrm{Ca}^{2+}$ (Fig. 2B). Equilibrium dissociation constants, $K_{\mathrm{D}}$, for the interaction of $\mathrm{Zn}^{2+}$ with APC are the means \pm SE from 3-4 tryptophan fluorescence titrations (Fig. 5).

\begin{tabular}{llllll}
\hline APC form & Additions & $K_{\mathrm{M}}(\mu \mathrm{M})$ & $k_{\text {cat }}\left(\mathrm{s}^{-1}\right)$ & $K_{\mathrm{I}}(\mu \mathrm{M})$ & $K_{\mathrm{D}}(\mu \mathrm{M})$ \\
\hline APC & EDTA & $270 \pm 30$ & $20 \pm 1$ & - & - \\
APC & $\mathrm{Zn}^{2+}$ & $140 \pm 50$ & $2.7 \pm 0.2$ & $13 \pm 1$ & $7.4 \pm 1.5$ \\
APC & $\mathrm{Ca}^{2+}$ & $350 \pm 70$ & $18 \pm 1$ & - & - \\
APC & $\mathrm{Ca}^{2+}+\mathrm{Zn}^{2+}$ & $360 \pm 80$ & $10 \pm 1$ & $57 \pm 4$ & $20 \pm 3$ \\
Des-Gla APC & $\mathrm{Zn}^{2+}$ & $\mathrm{nd}^{\mathrm{a}}$ & $\mathrm{nd}^{\mathrm{a}}$ & $25 \pm 3$ & $19 \pm 3$ \\
\hline${ }^{\mathrm{a}}$ nd; not determined & & & &
\end{tabular}




\section{What is known about this topic?}

- It is known that activated protein C (APC) has several binding sites for $\mathrm{Ca}^{2+}$, one in the serine protease domain, one in the EGF-1 domain and nine in the GLA domain. Additionally, APC has one $\mathrm{Na}^{+}$-binding site in the serine protease domain.

- It is known that binding of $\mathrm{Ca}^{2+}$ to the serine protease domain is required for the activation of protein $\mathrm{C}$ by the thrombin-thrombomodulin complex.

- The binding of $\mathrm{Ca}^{2+}$ and $\mathrm{Na}^{+}$to the serine protease domain allosterically regulate APC, resulting in enhanced enzymatic activity.

\section{What does this paper add?}

- This article shows that $\mathrm{Zn}^{2+}$ reversibly inhibits APC by a non-competitive mechanism. Inhibition occurs both with a chromogenic peptide and factor $\mathrm{Va}$ as substrates.

- This article further shows that the interaction of $\mathrm{Zn}^{2+}$ with APC is accompanied by a $\sim 40 \%$ decrease in tryptophan fluorescence. Apparent $K_{\mathrm{D}}$ and $K_{\mathrm{I}}$ values in the low micromolar range suggest that the inhibition may be relevant for the anticoagulant functions of APC.

- Finally, this article presents several amino acid clusters that are potential sites for $\mathrm{Zn}^{2+}$ binding. 


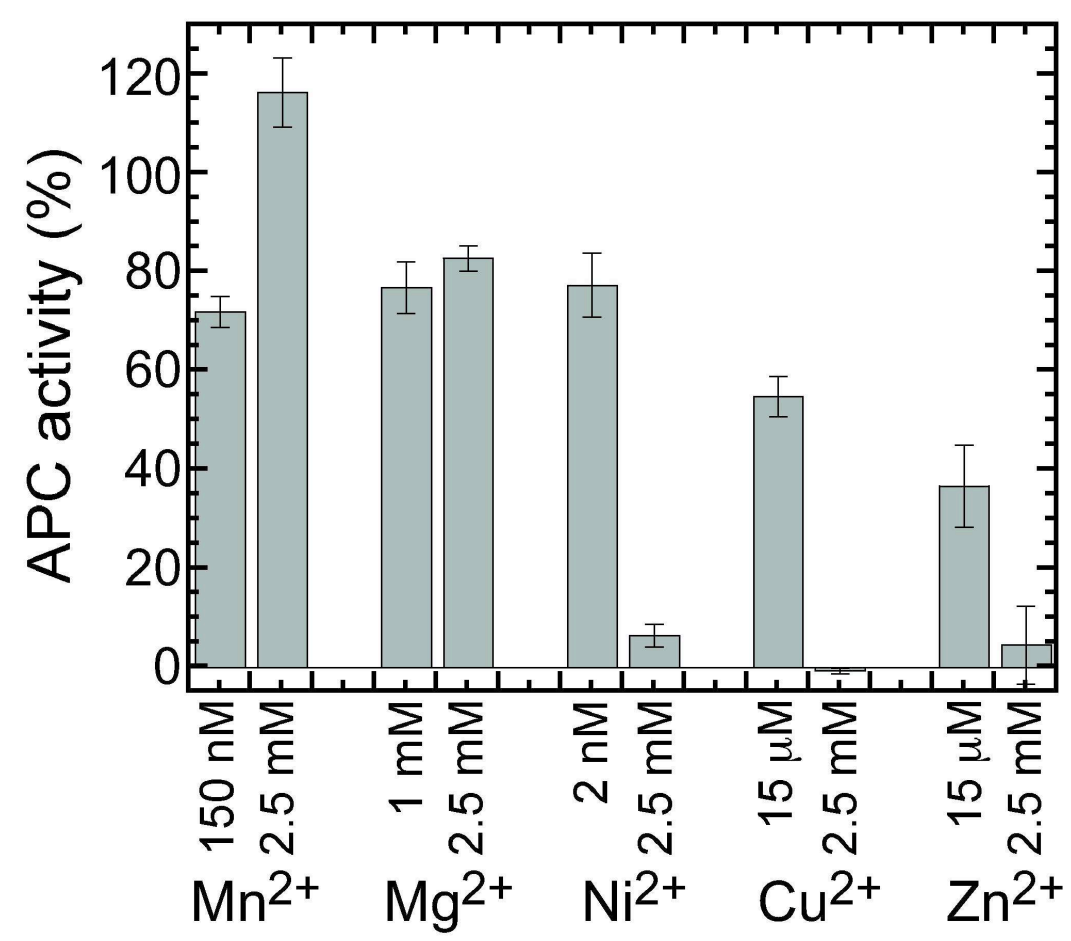

Fig.1. Zhu et al $106 \times 81 \mathrm{~mm}(600 \times 600$ DPI $)$ 
A

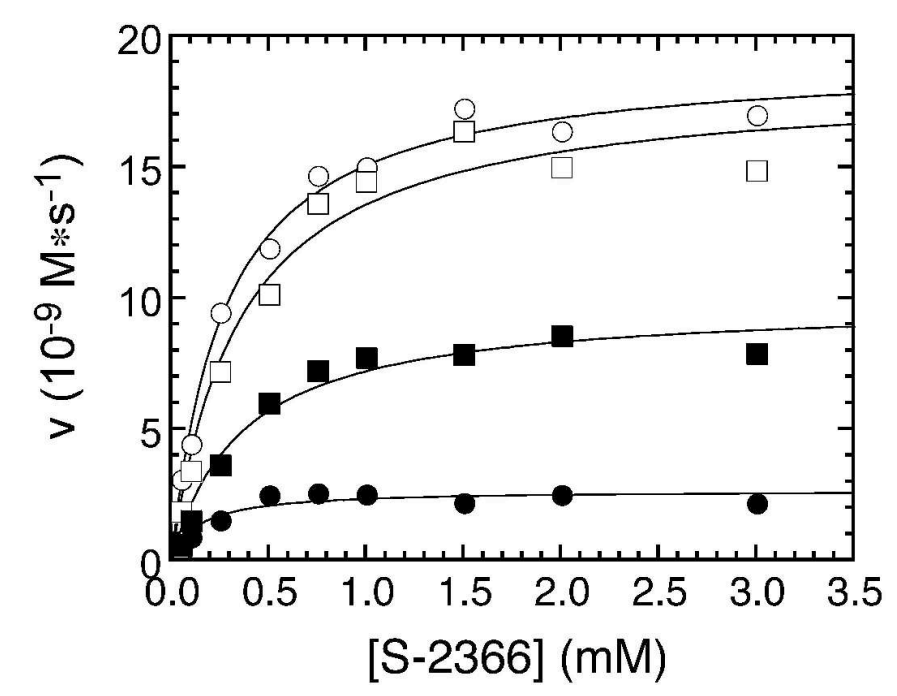

B

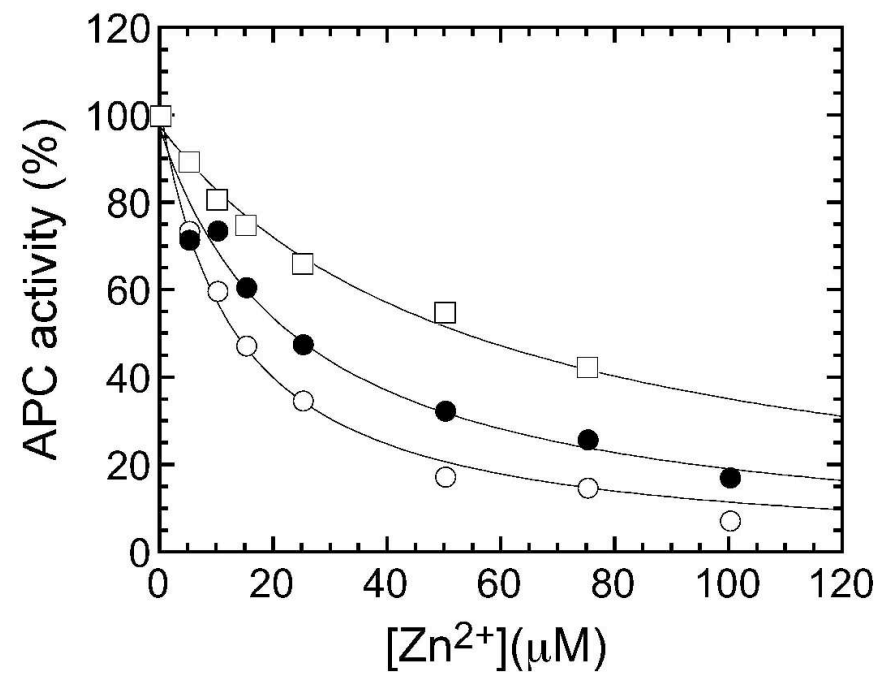

Fig.2. Zhu et al $107 \times 162 \mathrm{~mm}(600 \times 600 \mathrm{DPI})$ 
A

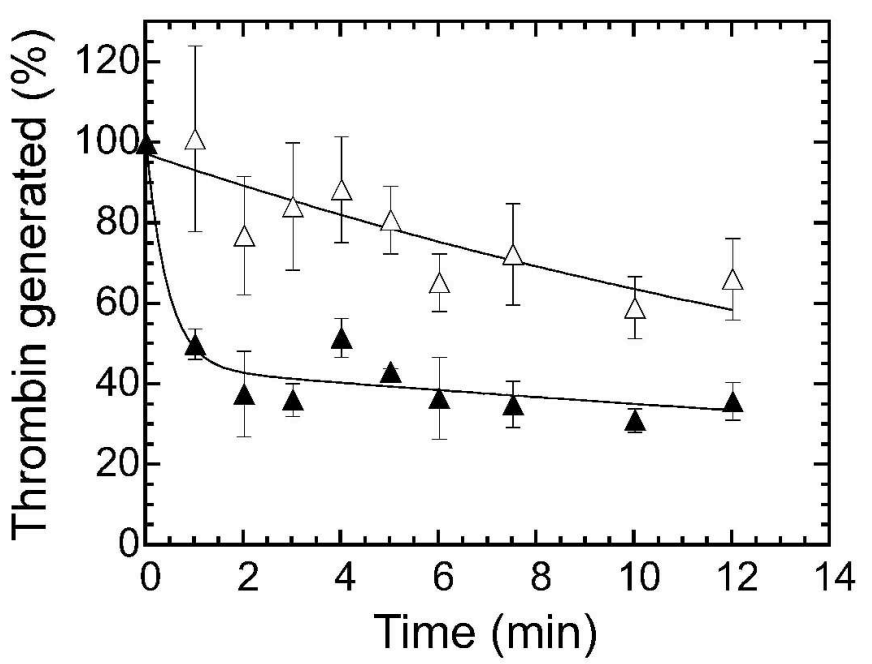

B

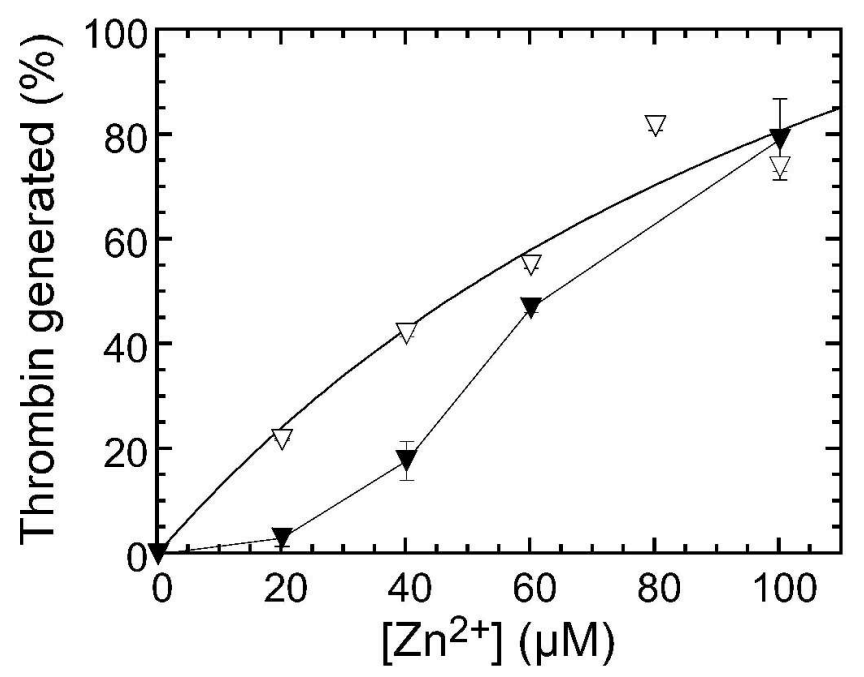

Fig.3. Zhu et al $107 \times 162 \mathrm{~mm}(600 \times 600$ DPI $)$ 
A

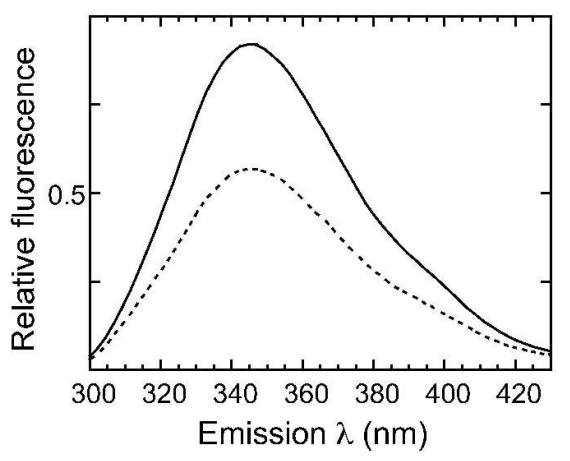

B

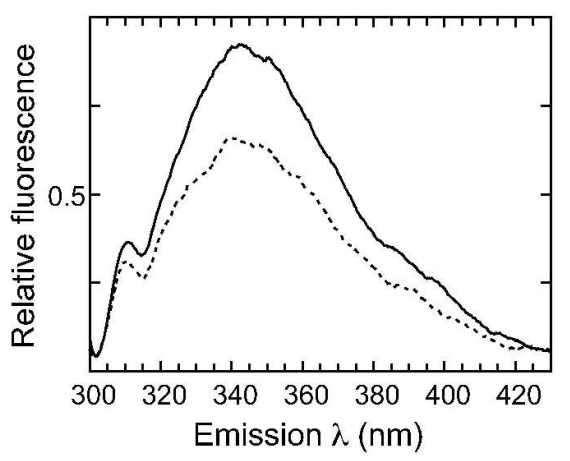

C

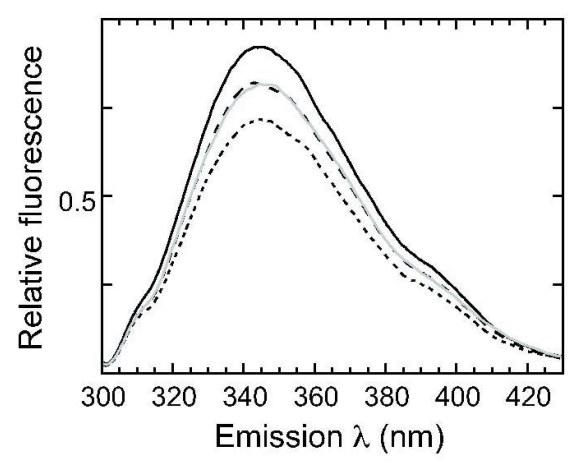

Fig.4. Zhu et al $106 \times 241 \mathrm{~mm}(600 \times 600$ DPI $)$ 
Page 35 of 36

Thrombosis and Haemostasis

1
2
3
4
5
6
7
8
9
10
11
12
13
14
15
16
17
18
19
20
21
22
23
24
25
26
27
28
29
30
31
32
33
34
35
36
37
38
39
40
41
42
43
44
45
46
47
48
49
50
51
52
53
54
55
56
57
58
59
60

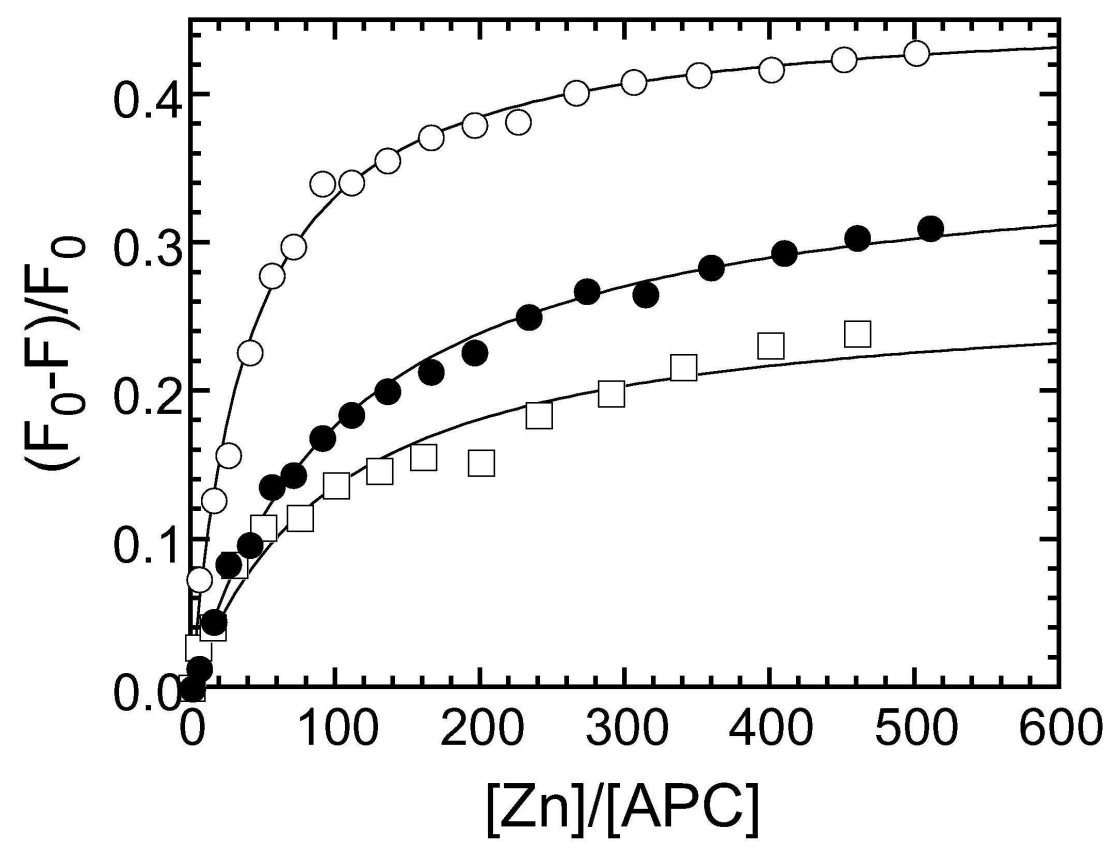

Fig.5. Thu et al

$106 \times 81 \mathrm{~mm}(600 \times 600$ DPI $)$ 

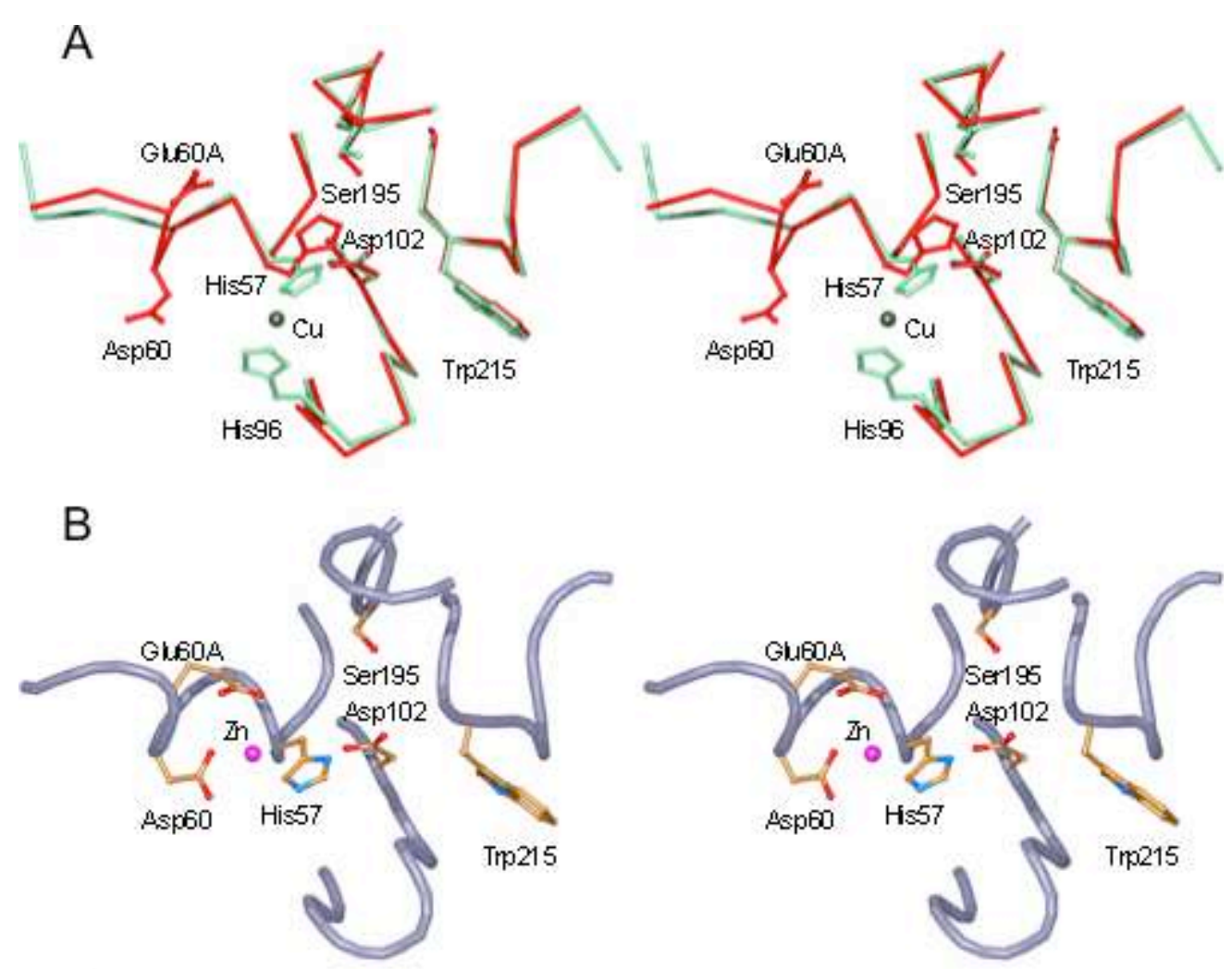

\section{C}
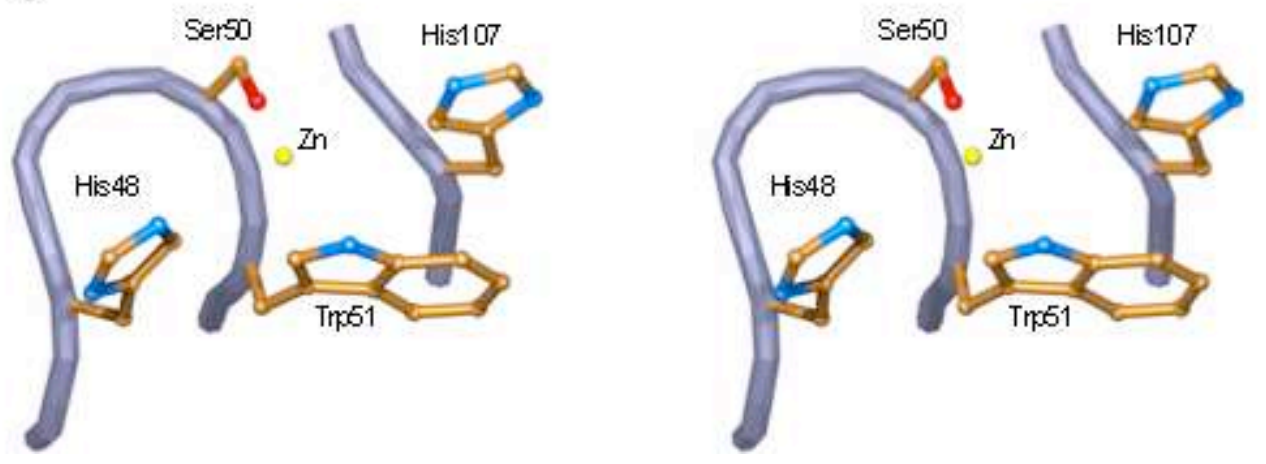

Fig. 6. Zhu et al $176 \times 207 \mathrm{~mm}(72 \times 72$ DPI $)$ 